\title{
Large-scale dispersal of the larvae of nearshore and pelagic fishes in the tropical oceanic waters of French Polynesia
}

\author{
A. Lo-Yat ${ }^{1,2}$, M. G. Meekan ${ }^{2, *}$, J. H. Carleton ${ }^{3}$, R. Galzin ${ }^{1}$ \\ ${ }^{1}$ Ecole Pratique des Hautes Etudes, UMR 8046 Centre National de la Recherche Scientifique, Laboratoire d'Ichtyoécologie \\ Tropicale et Méditerranéenne, Université de Perpignan, 6680 Perpignan CEDEX, France \\ ${ }^{2}$ Australian Institute of Marine Science, PO Box 40197, Casuarina MC, Northern Territory 0811, Australia \\ ${ }^{3}$ Australian Institute of Marine Science, PMB 3, Townsville MC, Queensland 4810, Australia
}

\begin{abstract}
The larvae of tropical pelagic and reef fishes were sampled from October 1995 to August 1997 using a very large fry pelagic trawl at sites between 4 and $20^{\circ} \mathrm{S}$ and 134 and $154^{\circ} \mathrm{W}$ in the region of the Society, Tuamotu and Marquesas Archipelagos in French Polynesia. Sites were selected on the basis of longline catches of adult tuna (a predator of larval reef fishes) and acoustic surveys of micronekton to a depth of $600 \mathrm{~m}$. A total of 3369 larvae were collected by 93 net tows. Most were late-stage larvae representing 29 taxa, of which 26 were predominantly reef fishes. Samples were dominated by acanthurids ( $43 \%$ ), pleuronectiform larvae, ostraciids, fistularids, balistids, holocentrids, chaetodontids, mullids and carangids. Distance to reefs was the principal factor determining clustering patterns in classification and ordination analyses, and offshore samples (>150 km from reefs) were dominated by pelagic species, while collections nearer to reefs were dominated by coral reef species. There was a linear decline in richness of samples with increasing distance from reefs and an exponential decline in abundance, so that few reef fish larvae were collected $>300 \mathrm{~km}$ from adult reef habitats. However, abundances of up to hundreds of reef fish larvae per hour of net tow were collected $>100 \mathrm{~km}$ from the nearest reef. Our results show that relatively little connectivity is likely among reef systems separated by $>300 \mathrm{~km}$ in French Polynesia, but substantial exchange of larvae within a restricted range of reef fish taxa might occur at smaller spatial scales.
\end{abstract}

KEY WORDS: Dispersal $\cdot$ Coral reef $\cdot$ Fish larvae $\cdot$ Plankton net $\cdot$ Connectivity $\cdot$ Reef fish Resale or republication not permitted without written consent of the publisher

\section{INTRODUCTION}

Traditionally, populations of coral reef fishes were viewed as 'open', where pelagic larvae were exchanged among patches of habitat occupied by adults at broad spatial scales (hundreds to thousands of kilometres). A variety of recent evidence has led to a reversal of this idea, so that, today, populations are thought to be substantially 'closed' (i.e. self-recruiting) at scales as small as a single coral reef. This shift in thought has been driven by the outcome of studies in the fields of genetics, physical oceanography and larval behaviour, and of tagging and modelling studies of the dispersal patterns of larval coral reef fishes (for reviews see Leis 2002, Mora \& Sale 2002, also Taylor \& Hellberg 2003, Paris \& Cowen 2004).

Modelling studies have made an important contribution to this debate, as they provide a means to examine dispersal of reef fish larvae at very large spatial scales. For example, Roberts (1997) modelled the dispersal patterns of reef fish larvae based on surface currents over the entire Caribbean Sea, while Cowen et al. (2000) modelled the dispersal of larval reef fishes over an area of thousands of square kilometres of the eastern Caribbean, centered on Barbados. Incorporating estimates of larval diffusion and mortality and assum- 
ing passive dispersal of larvae in surface currents, Cowen et al.'s (2000) model predicted that very few pelagic larvae would be found $>140 \mathrm{~km}$ offshore from a source population of benthic adults.

At present, it is very difficult to validate dispersal models, as larvae cannot be tracked in the plankton throughout their entire pelagic lives and distributions of larval reef fishes are rarely sampled in the field at sufficiently large spatial scales. Some evidence against which model outcomes can be judged is provided by Clarke (1995), who used a large mid-water trawl (3 m mouth opening, $6 \mathrm{~mm}$ mesh size) to sample larval fish distributions over $40^{\circ}$ of latitude in the central equatorial Pacific between Tahiti and Hawai'i. As predicted, he found that catches of larvae declined with distance from reefs. However, many taxa were collected up to $300 \mathrm{~km}$ from the nearest landmass. Other evidence that long distance dispersal of reef fish larvae occurs at least occasionally is shown by the presence of larval fish in oceanic waters remote from any reef (Leis 1983, 1984, Victor 1987, Victor \& Wellington 2000) and the colonisation by species (often during climatic events such as El Niño) of new reef habitats many hundreds of kilometres from potential sources of larval supply (Cowen 1985, Robertson \& Allen 1996).

To date, Clarke's (1995) study provides the only example of the distribution of larval reef fishes in tropical waters at very large scales (hundreds to thousands of kilometres); consequently there is little evidence on which to determine the generality of his results. He sampled stations at regular intervals (approximately $1^{\circ}$ of latitude) along 3 transects perpendicular to the major current flows in the region. Recent studies show that much small scale (m to $\mathrm{km}$ ) structure exists in the distribution of larval fishes in open water (Kingsford 1993), which such systematic sampling may miss. Thus, the extent to which distribution patterns of larval fishes support recent models of dispersal and survivorship in the waters around coral reefs remains unresolved.

Here, we describe the distribution patterns of the larvae of coral reef fishes over $16^{\circ}$ of latitude and $20^{\circ}$ of longitude in the waters of French Polynesia. Our data sets were collected as part of a study on the food and feeding habitats of tuna (Etude du comportment des thonidés par acoustique et par pêche: ECOTAP, Bertrand et al. 1999, 2002). This program used experimental longline fishing to locate tuna. Where this technique was successful, acoustics and a very large (17 $\mathrm{m}$ mouth opening) midwater fry plankton net were then used to describe the distributions of their micronekton (1 to $10 \mathrm{~cm}$ size) prey, which included larval reef fishes. Unlike traditional approaches to characterising larval fish distributions, which sample systematically on a spatial or temporal basis, this method effectively used the open water predators of larval fishes to identify places where and times when fish larvae were abundant in the plankton. This meant that they could be targeted by acoustics and net tows that filtered very large volumes of water. In the present study, we compare distributions of fish larvae sampled using this technique with predictions of models of larval dispersal from reefs and use our results to predict the probable limits of dispersal for some common taxa of reef fishes.

\section{MATERIALS AND METHODS}

Collection. The ECOTAP programme examined the spatial distribution of tunas by longline sampling, and used acoustics to map the density of the micronekton on which tuna feed. Mid-water trawls were then used to characterise micronekton, and the stomach contents of tuna from longlines were examined to confirm the use of micronekton as prey. Details of the methods and results of ECOTAP are given in Bertrand et al. (1999, 2002). Here, we describe spatial patterns in the component of larval pelagic and nearshore fishes from net samples.

The study was conducted from October 1995 to August 1997 on board the $28 \mathrm{~m}$ RV 'Alis', between 4 and $20^{\circ} \mathrm{S}$ and 134 and $154^{\circ} \mathrm{W}$ across the Society, Tuamotu and Marquesas Archipelagos (Fig. 1). Larval

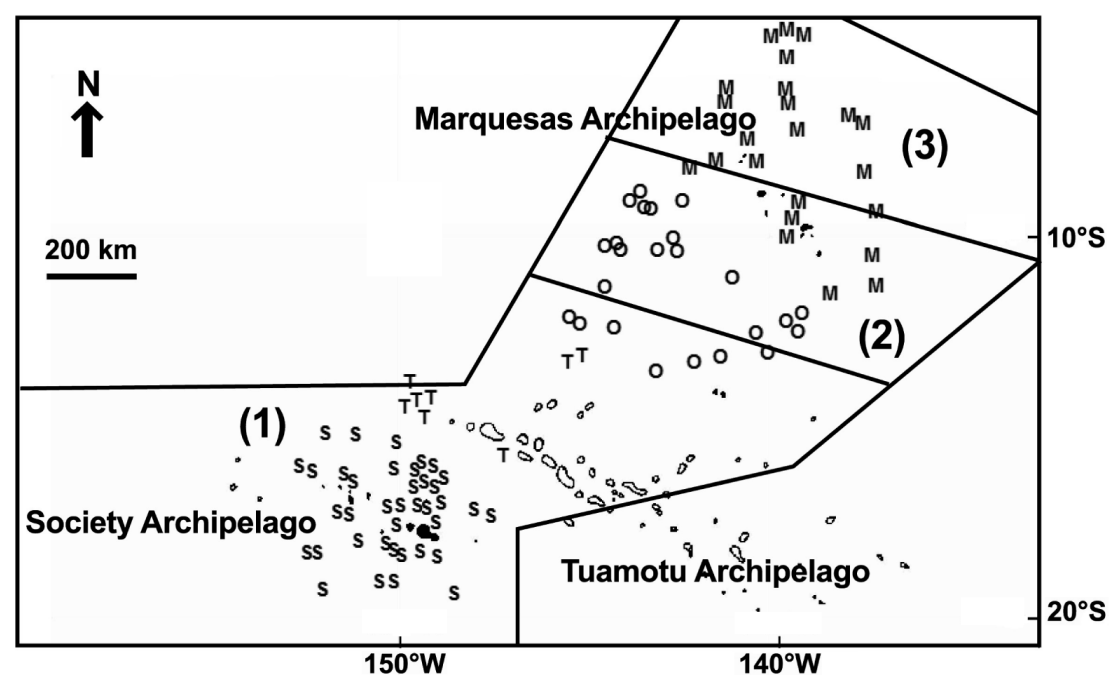

Fig. 1. Location map. Sampling sites are coded (M: Marquesas; T: Tuamotu; S: Society Archipelagos). Oceanic (O) sampling sites were generally $>90 \mathrm{~km}$ from the nearest reef. Zones 1 to 3 are defined on the basis of micronekton abundance according to Bertrand et al. (1999) (see 'Materials and methods') 
fish were sampled with a fry pelagic trawl, with a variable-opening mouth of up to $17 \mathrm{~m}$ and a total length of $50 \mathrm{~m}$. The net was constructed of $80 \mathrm{~mm}$ mesh at the mouth, which decreased to $5 \mathrm{~mm}$ mesh at the cod end. The net targeted concentrations of micronekton detected by an echosounder within the upper $600 \mathrm{~m}$ of the water column. A total of 93 net tows from 10 cruises were analysed for the present study. On average, these tows were of 48 min duration at a boat speed of 3 knots and covered a distance of 2.42 nautical miles or $4.5 \mathrm{~km}$. Sites of each net tow are shown in Fig. 1. The net was sampled during the day and at night as well as at variable depths, due to the changes in the distribution of micronekton. Catches were frozen once washed from the net. In the laboratory, samples were sorted, and each taxonomic group was counted. Fish were identified to the family level when possible.

At each site a CDT attached to the net was used to sample the salinity, water temperature and density of the water column. Estimates of sea surface temperature (SST) were obtained by averaging values at the start and end of each tow.

Statistical analysis. We did not attempt to convert our samples to concentrations of larvae based on the volume of water filtered by the net. Nearly all the fish captured by the net were late-stage larvae, which have highly developed sensory and locomotory systems that make them capable of avoiding even large towed nets (Choat et al. 1993). Thus, despite targeting of sampling and the large net used by the ECOTAP programme, we have almost certainly underestimated the abundance of such larvae in oceanic waters. Furthermore, aggregations of microzooplankton were sampled in the water column, which tended to cause rapid clogging of the cod end where aggregations were dense and contained abundances of jellyfish. For these reasons, we expressed catches in terms of numbers of larvae per hour of sampling. These same problems exist, to varying degrees, in most other studies that use net tows to sample late-stage larvae (Heath 1992).

Association among the taxa of reef fishes collected during the study was examined by agglomerative hierarchical classification using Bray-Curtis dissimilarity coefficients and UPGMA fusion strategy (beta $=-0.1$ ) based on presence/absence data. To interpret the cluster analysis, samples were identified by season (wetNovember to April, dry-May to October), day (06:00 to $18: 00 \mathrm{~h})$, night (18:00 to $06: 00 \mathrm{~h}$ ) and 'zone'. The latter coding was based on previous results of the ECOTAP programme (Bertrand et al. 1999), where Zone 1 was located south of $13^{\circ} \mathrm{S}$, had a very low biomass and a small number of micronekton aggregates (as determined from acoustic data); Zone 2 was located between 8 and $13^{\circ} \mathrm{S}$, was characterised by the highest biomass and a large number of micronekton aggre- gates; while Zone 3 was located north of $8^{\circ} \mathrm{S}$, had a low biomass and few micronekton aggregates (Fig. 1). Samples were further defined by their proximity to island archipelagos (Society, Tuamotu and Marquesas). Samples taken from sites between the Tuamotu and Marquesas Archipelagos, but which were remote from these island chains (>90 km, average distance $240 \mathrm{~km}$ ), were defined as 'oceanic' (Fig. 1).

Following this analysis the same data sets were subjected to principal coordinate analysis using the Bray-Curtis metric and presence/absence data. Oneway ANOVAs were used to examine the influence of physical parameters (average SST, salinity, depth and time) on the occurrence (number per hour) of reef fish taxa during the 10 ECOTAP cruises.

\section{RESULTS}

\section{Composition}

A total of 3369 fish larvae were collected during the 93 net tows. The majority of these were late-stage larvae (Table 1). Catches were composed of 29 taxa, of which 26 belonged to reef fish families, accounting for approximately $30 \%$ of the families of adult reef fish that have been recorded in French Polynesia (Randall 1985). Samples were dominated by acanthurids (43\% of total numbers), pleuronectiform larvae, ostraciids (represented by a single species, Lactoria diaphana), fistularids, balistids, holocentrids, chaetodontids, mullids and carangids. Together these taxa composed $85 \%$ of catches (Table 1). As the ostraciid was a species that was pelagic throughout its entire life history, it was excluded from analyses that focused on the abundance of late-stage larvae as related to distance from shore (Clarke 1995).

\section{Spatial patterns}

Nine groups of samples were defined from the cluster analysis (Fig. 2). The first split separated samples that contained only 1 taxon of reef fish (Group 9), while the second split (Group 8) divided a small group of samples collected from the Marquesas Archipelago during the wet season from all other catches. The next split separated samples from micronekton Zones 1 and 2. Samples from Zone 3 were spread throughout all groups. Catches from Zone 2 formed clusters based on sites sampled in the dry season (Group 1) and a mix of sites sampled during the wet season (Groups 2 and 3). Catches from Zone 1 split into clusters formed primarily from samples from the Society Archipelago and samples from a mix of sites collected during the wet 
Table 1. Catches of nearshore and pelagic larvae collected by net tows in French Polynesia. Shown are the number of times each taxon was collected during the study (Tows), the total number (No.), the minimum (Min.) and maximum (Max.) standard length (SL) of larvae in samples and the minimum and maximum distance from the nearest reef where larvae were collected. Total numbers collected $<150$ and $>150 \mathrm{~km}$ from the nearest reef are shown for each taxon. A summary of Clarke's (1995) samples from the central equatorial Pacific between Hawai'i and French Polynesia are provided for comparison. Only those taxa that were also collected by the present study are shown

\begin{tabular}{|c|c|c|c|c|c|c|c|c|c|c|c|c|c|}
\hline \multirow{3}{*}{ Taxon } & \multirow{3}{*}{ Tows } & \multirow{3}{*}{ No. } & \multicolumn{6}{|c|}{ - Present study - } & \multirow{3}{*}{ No. } & \multicolumn{4}{|c|}{ - Clarke (1995) } \\
\hline & & & \multicolumn{2}{|c|}{ SL (mm) } & \multicolumn{2}{|c|}{ Distance $(\mathrm{km})$} & \multirow{2}{*}{$\begin{array}{l}\text { No. } \\
<150\end{array}$} & \multirow{2}{*}{$\begin{array}{c}\text { No. } \\
>150\end{array}$} & & \multicolumn{2}{|c|}{$\mathrm{SL}(\mathrm{mm})$} & \multicolumn{2}{|c|}{ Distance $(\mathrm{km})$} \\
\hline & & & Min. & Max. & Min. & Max. & & & & Min. & Max. & Min. & Max. \\
\hline \multicolumn{14}{|l|}{ Reef fish larvae } \\
\hline Acanthuridae & 51 & 1411 & 5 & 51 & 2 & 341 & 931 & 480 & 25 & 2 & 30 & 35 & 994 \\
\hline Pleuronectiforms & 45 & 289 & 10 & 45 & 2 & 341 & 169 & 120 & 25 & 5 & 138 & 44 & 555 \\
\hline Holocentridae & 18 & 224 & 12 & 49 & 4 & 185 & 208 & 16 & 8 & 3 & 8 & 44 & 993 \\
\hline Chaetodontidae & 14 & 133 & 5 & 29 & 4 & 185 & 125 & 8 & 3 & 5 & 12 & 35 & 525 \\
\hline Mullidae & 15 & 123 & 16 & 94 & 4 & 133 & 123 & 0 & 5 & 11 & 20 & 740 & 1131 \\
\hline Fistularidae & 21 & 98 & 20 & 172 & 2 & 270 & 66 & 32 & 2 & 84 & 86 & 44 & 140 \\
\hline Pomacanthidae & 8 & 44 & 10 & 22 & 37 & 272 & 29 & 16 & 8 & 7 & 16 & 44 & 496 \\
\hline Lutjanidae & 8 & 40 & 17 & 121 & 2 & 167 & 22 & 18 & 2 & 9 & 10 & 35 & 158 \\
\hline Priacanthidae & 7 & 27 & 9 & 43 & 4 & 211 & 24 & 3 & 1 & 9 & 9 & 272 & 272 \\
\hline Scorpaenidae & 6 & 25 & 10 & 16 & 2 & 326 & 19 & 6 & 28 & 4 & 29 & 44 & 987 \\
\hline Apogonidae & 2 & 22 & 20 & 25 & 98 & 106 & 22 & 0 & 5 & 4 & 25 & 44 & 522 \\
\hline Synodonthidae & 3 & 16 & 38 & 46 & 2 & 144 & 16 & 0 & 8 & 20 & 34 & 24 & 140 \\
\hline Tetraodontidae & 10 & 12 & 9 & 32 & 4 & 243 & 8 & 4 & 1 & 21 & 21 & 140 & 140 \\
\hline Hemiramphidae & 8 & 10 & 42 & 57 & 41 & 363 & 1 & 9 & - & - & - & - & - \\
\hline Eleotrididae & 2 & 9 & 22 & 33 & 4 & 65 & 9 & 0 & 4 & 5 & 7 & 140 & 140 \\
\hline Sphyraenidae & 1 & 8 & 32 & 41 & 37 & 37 & 1 & 0 & - & - & - & - & - \\
\hline Kyphosidae & 3 & 6 & 18 & 68 & 111 & 211 & 2 & 4 & - & - & - & - & - \\
\hline Monacanthidae & 2 & 6 & 28 & 42 & 4 & 96 & 6 & 0 & - & - & - & - & - \\
\hline Zanclidae & 1 & 6 & 45 & 45 & 15 & 15 & 6 & 0 & - & - & - & - & - \\
\hline Lethrinidae & 2 & 6 & 30 & 48 & 22 & 41 & 6 & 0 & 1 & 23 & 23 & 993 & 993 \\
\hline Pomacentridae & 3 & 5 & 15 & 22 & 61 & 241 & 1 & 4 & 13 & 7 & 16 & 35 & 987 \\
\hline Malacanthidae & 2 & 4 & 32 & 60 & 4 & 22 & 4 & 0 & - & - & - & - & - \\
\hline Dactylopteridae & 2 & 3 & 14 & 18 & 22 & 241 & 2 & 1 & - & - & - & - & - \\
\hline Serranidae & 2 & 3 & 23 & 29 & 41 & 211 & 2 & 1 & 89 & 3 & 29 & 24 & 994 \\
\hline Aulostomidae & 2 & 2 & 99 & 107 & 74 & 150 & 1 & 1 & - & - & - & - & - \\
\hline Siganidae & 1 & 1 & 32 & 32 & 18 & 18 & 1 & 0 & - & - & - & - & - \\
\hline Balistidae & 19 & 232 & 7 & 48 & 2 & 211 & 220 & 12 & 1 & 5 & 5 & 1140 & 1140 \\
\hline Carangidae & 15 & 83 & 10 & 80 & 22 & 211 & 22 & 61 & 9 & 3 & 20 & 35 & 1131 \\
\hline \multicolumn{14}{|l|}{ Pelagic larvae } \\
\hline Ostraciidae & 35 & 279 & 6 & 41 & 4 & 444 & 77 & 202 & 6 & 7 & 18 & 140 & 994 \\
\hline Unidentified & 30 & 240 & & & & & & & & & & & \\
\hline Total & & 3369 & & & & & & & 244 & & & & \\
\hline
\end{tabular}

season (Group 7). The cluster of samples from sites in the Society Archipelago further disassociated into groups of samples collected during the night in the dry (Group 4) and wet (Group 5) seasons and samples collected during the day (Group 6).

The results of ordination analysis confirmed the patterns identified by cluster analysis (Fig. 3). Dimension 1 accounted for $27.5 \%$ of the variability in catches. Acanthurids, ostraciids (Lactoria diaphana) and pleuronectiforms were the 3 larval fish taxa that contributed most to the separation of groups in the ordination. Acanthurids were present in more samples from Zone 1 (Groups 4, 5, 6 and 7), while ostraciids were present in oceanic samples (Group 1), and occurrences of pleuronectiform larvae were higher in Group 2. The majority of vectors of taxa pointed towards Groups 4, 5 and 6 , which were dominated by samples from the
Society Archipelago. The number of taxa (richness) was significantly higher in Group 4, which was mostly composed of samples from sites near the Society Islands (Fig. 4A).

Groups 4 and 5 had the greatest occurrence of reef fish larvae (26 and $10 \%$ of composition, respectively). These were mostly sampled at night in Zone 1, principally at sites in the Society Islands. The lowest proportion of larval reef fishes occurred in Groups 3 and 9 (0.5 and $0.7 \%$, respectively), both of which were composed of sites at large distances from the nearest reef.

Distance to the nearest reef was highly correlated with oceanic sites and the family Ostraciidae, while SST, salinity and depth of sampling had lower correlations with the ordination axes. Groups of samples taken at sites that were the greatest distance from reefs were to the left of the centre of the plot (Groups 1, 


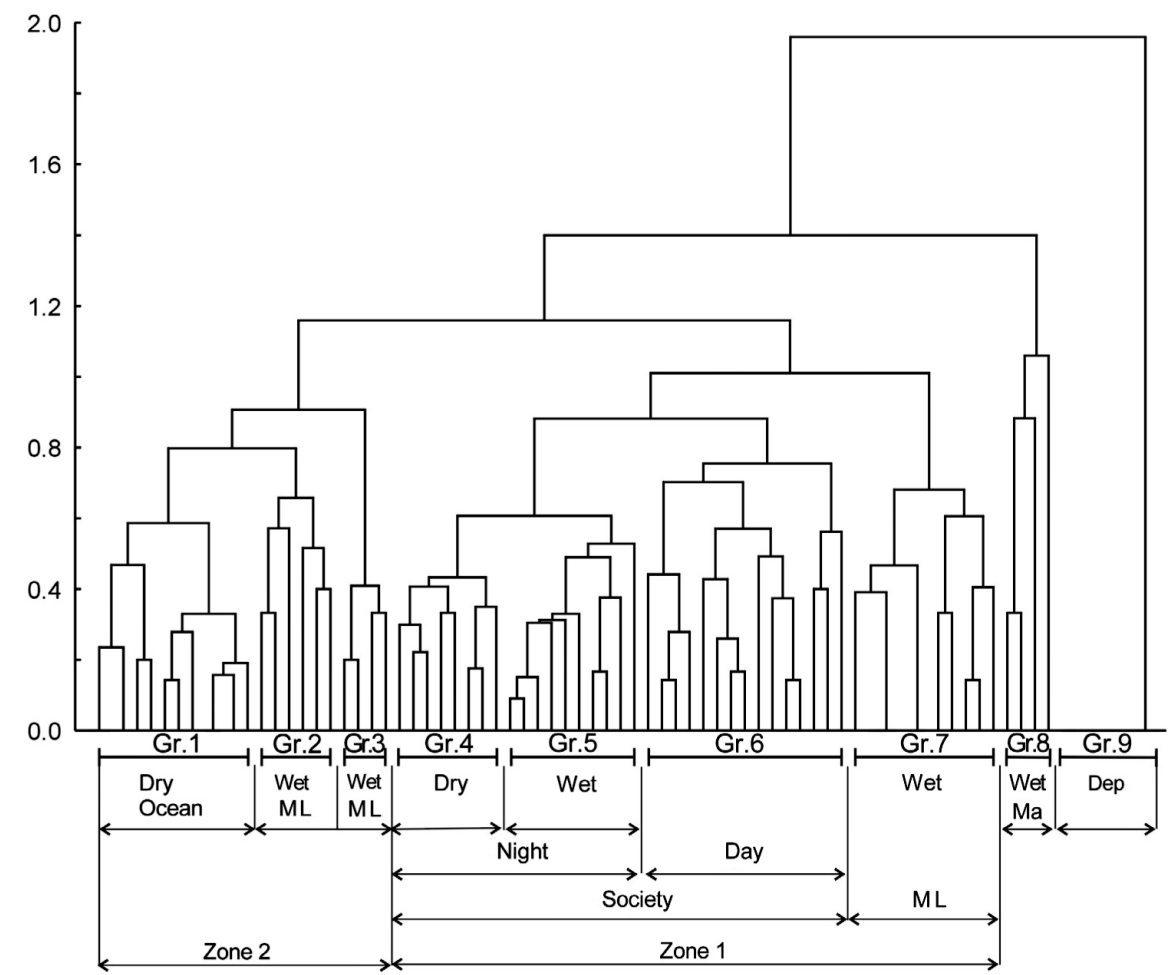

Fig. 2. Dendrogram from classification analysis of larval pelagic and nearshore fishes obtained from net samples in French Polynesia. Zones 1 to 3 defined on the basis of micronekton abundance according to Bertrand et al. (1999) (see 'Materials and methods'). For descriptions of Groups 1-9 see 'Results'. Dry: dry season samples; Wet: wet season; Ocean: oceanic, sample sites $>90 \mathrm{~km}$ from the nearest reef; Ma: Marquesas Archipelago; Society: Society Archipelago; ML: mixed locations; Dep: depauperate sample containing only 1 taxon of reef fish significant differences in either richness or abundance between samples collected during the day and night ( $t$-tests, $\mathrm{p}=0.32$ and $\mathrm{p}=0.50$, respectively).

Analysis of catches of nearshore fish larvae (excluding the pelagic ostraciid) showed a significant linear decline in richness of samples with increasing distance offshore (Fig. 6A). The decline in abundance of nearshore fish larvae on this gradient was even more striking, with a significant negative exponential trend in the data set, so that while 100 s of nearshore fish larvae (per hour of tow) were collected close to reefs, very few were captured beyond $300 \mathrm{~km}$ from the nearest adult habitat (Fig. 6B).

\section{DISCUSSION}

The ECOTAP programme collected $>3000$ predominantly late-stage fish larvae in the waters of French Polynesia. As predicted by dispersal models, there was an exponential decline in abundance of catches with increasing
2, 3, 8 and 9), while groups closer to reefs were to the right (Groups 4, 5, 6 and 7). Fig. 4B shows the average distance for each of these groups.

Average SST at our sampling sites ranged from 26.6 to $29.5^{\circ} \mathrm{C}$. Richness of catches was significantly higher at the lowest temperature $\left(26.6^{\circ} \mathrm{C}\right)$ than at mid- or high temperatures (1-way ANOVA, p = 0.025; Fig. 5A). SST had no significant influence on the number of fish larvae captured per hour of sampling (1-way ANOVA, p = 0.71).

Richness of catches increased in samples collected at higher average salinities (1-way ANOVA, $p=0.00004$; Fig. 5B). There was a similar trend in the number of larvae captured per hour, although this was non-significant (1-way ANOVA, $p=0.31$ ).

The depth of net tows ranged from 59 to $274 \mathrm{~m}$. Richness was significantly lower in the deepest samples, while samples collected at mid- (140 m) and shallow $(59 \mathrm{~m})$ depths did not differ in richness (1-way ANOVA, p =0.02; Fig. 5C). Again, there was a similar (but non-significant) pattern in the numbers of larvae collected per hour with depth (1-way ANOVA, p=0.16). There were no

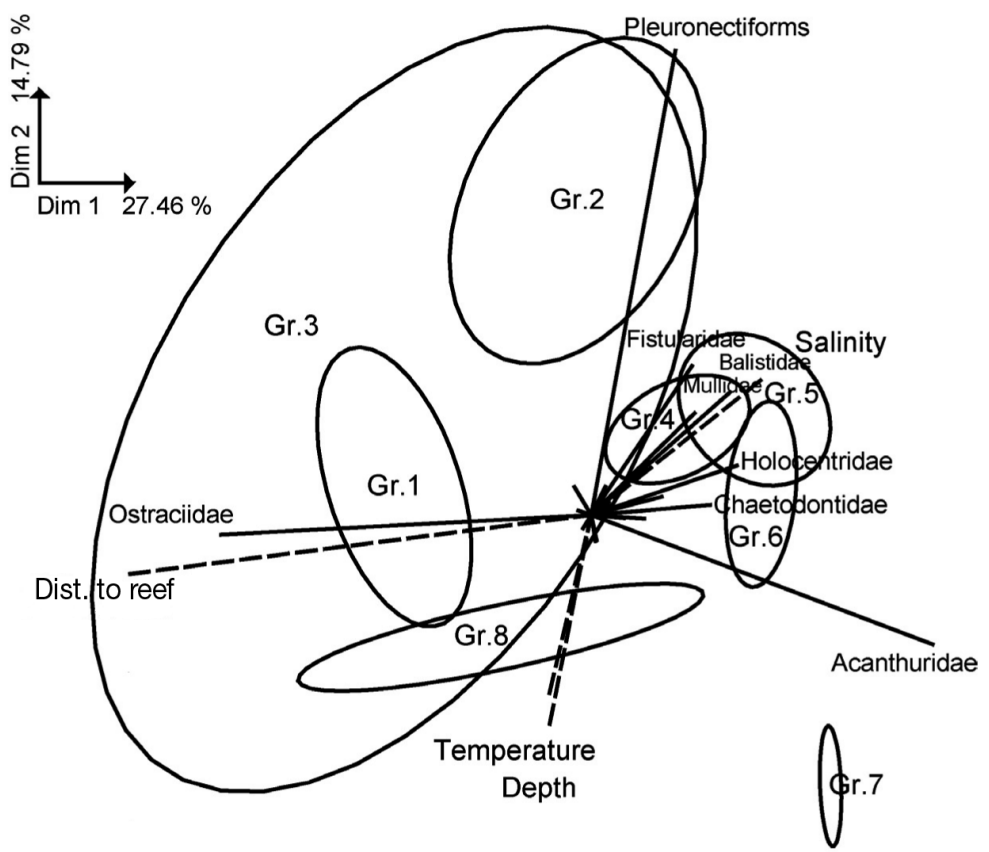

Fig. 3. Results of ordination analysis of larval pelagic and nearshore fishes obtained from net samples in French Polynesia. Groups (Gr. 1 to 8 ) correspond to clusters of samples formed by classification analysis (see Fig. 2). Physical factors and larval fish taxa contributing most to variation in data sets are shown 


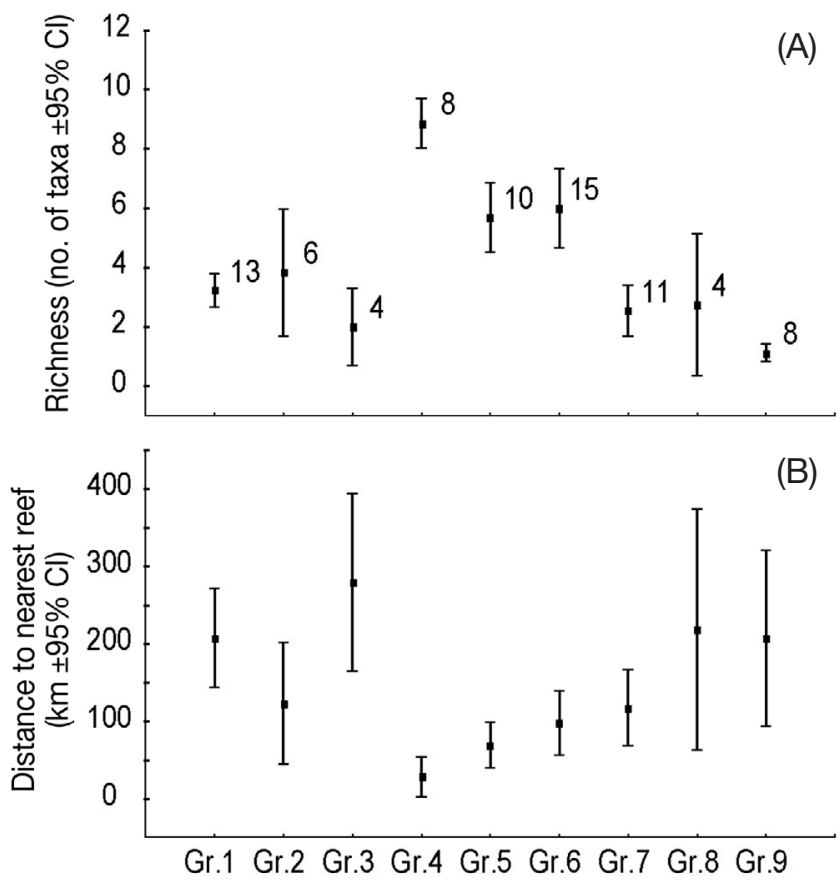

Fig. 4. (A) Average richness (number of taxa $\pm 95 \%$ CI), (B) average distance to the nearest reef $(\mathrm{km}, \pm \mathrm{CI})$ of each group of samples (Gr. 1 to 8) identified by classification analysis (see Fig. 2). Number of samples in each group is shown in (A)

distance from the shore, so that very few reef fish larvae were collected $>300 \mathrm{~km}$ from the nearest adult habitats. This result shows that under the oceanographic conditions encountered by the ECOTAP study, relatively little connectivity is likely in this region among reef systems separated by such distances.

A steep decline in abundance of larval fishes from reef habitats with increasing distance offshore appears to be typical of many tropical localities. Similar to our study, Clarke (1995) recorded a sharp decline in abundance of reef fish larvae $>300 \mathrm{~km}$ from reefs at sites sampled in the central equatorial Pacific between Hawai'i and French Polynesia. At smaller spatial scales (10 to $50 \mathrm{~km}$ ), a number of tropical studies have reported declining numbers of larvae along cross-shelf transects (e.g. Young et al. 1986) or in oceanic waters offshore of isolated islands (Clarke 1991) or barrier reef systems (Leis 1991, 1993). To date, one of the major problems of interpretation of such patterns has been that these surveys of abundance have been sampled using small nets that filtered low volumes of water. Because of the relatively large volumes in which larvae are diluted offshore, gradients in abundance may simply reflect relatively low sampling efficiency at offshore sites (Clarke 1991, 1995). Furthermore, larvae dispersed into oceanic water will tend to be older, well developed forms, which are capable of avoiding nets (Choat et al. 1993, Clarke 1995), in contrast to the newly hatched and preflexion forms that dominate catches closer to shore (Leis 1991, 1993).

The ECOTAP programme confirms the results of these previous studies and suggests that strong offshore gradients in abundance of larvae are a real phenomenon, at least on a scale of hundreds of kilometres. Unlike earlier work, ECOTAP used a massive plankton net that filtered huge volumes of water to capture larval fish. Sampling was also structured to include larval fish predators (tuna) and sonar, so that the net targeted aggregations of larvae in the water column. Consequently, our results are robust as they are based on abundances of larvae that are an order of magnitude greater than those of previous studies (e.g. Clarke 1995).

Similar to abundance, richness of our catches also declined with increasing distance from reefs, albeit in a linear rather than an exponential fashion. Overall, richness of our collections was relatively low when compared with the study of Clarke (1995). This may have been due to the large mesh size of the net (80 mm, $5 \mathrm{~mm}$ mesh in cod end), which was principally designed to capture juvenile tunas. Smaller fish larvae
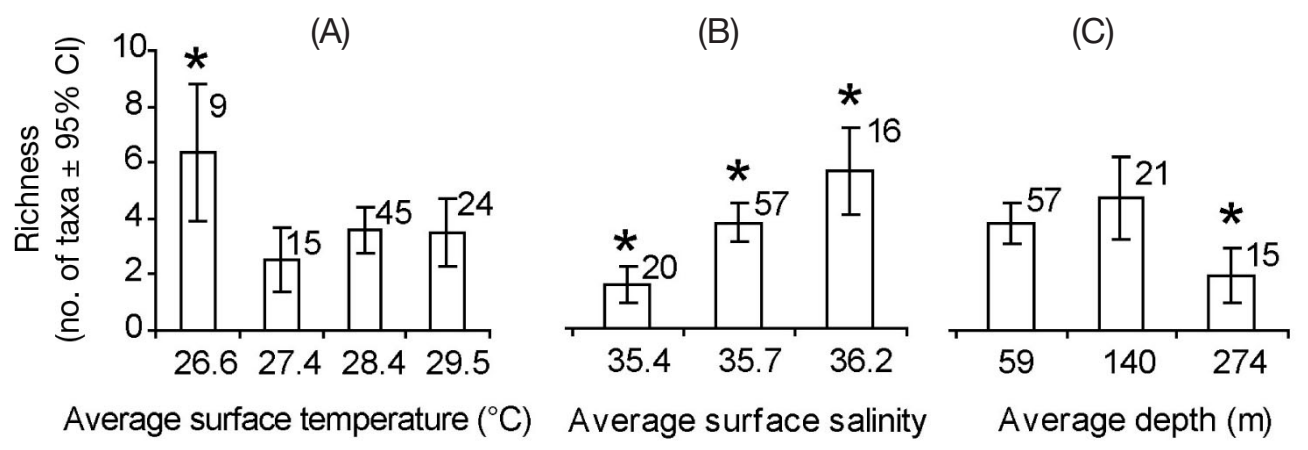

Fig. 5. Average richness (number of taxa $\pm 95 \%$ CI) of larval pelagic and nearshore fishes at differing average (A) sea surface temperature, (B) surface salinities and (C) depths collected by net tows in French Polynesia. Numbers of tows are shown over each bar. Results of least square difference tests are also shown: ${ }^{*}$ significantly different at $\mathrm{p}<0.05$ 


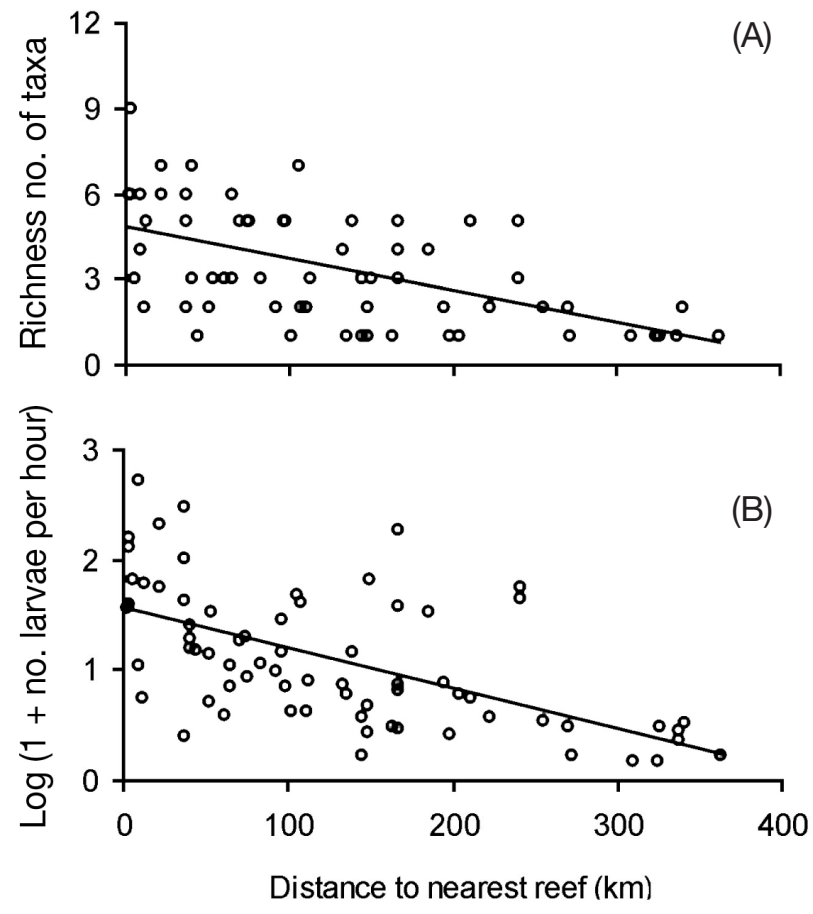

Fig. 6. (A) Richness (number of taxa) and (B) abundance (note log scale) of larval nearshore fishes (pelagic larvae excluded) versus increasing distance from the nearest reef $(\mathrm{n}=70)$. Least squares regression equation for richness: $4.815-0.011 \times$ distance to nearest reef $(\mathrm{r}=-0.562, \mathrm{p}<0.00001)$. Least squares regression equation for $\log (1+$ abundance $)$ : $1.564-$

$0.004 \times$ distance to nearest reef $(r=-0.589, \mathrm{p}<0.00001)$

may have escaped, restricting catches to larger taxa and pre-settlement larvae. Conversely, larger larvae were probably captured with greater efficiency through targeted sampling with a large net. Some evidence for this is provided by a comparison of minimum and maximum size ranges of larvae. Of the 21 taxa common to both, the minimum size of larvae from 18 taxa was smaller (by an average of $7.5 \mathrm{~mm}$ ) in Clarke's study than in the ECOTAP collections, while the maximum size of larvae from 19 taxa was greater (by an average of $31 \mathrm{~mm}$ ) in our study than in Clarke's (1995). The escape of small larval forms may also explain the lack of wrasse larvae in the ECOTAP catches. Larval wrasse have been found in oceanic waters remote from reefs (Leis 1983, 1984, Victor 1987), are known to be transported large distances by current systems (Hare \& Cowen 1991) and have previously been captured in oceanic waters near French Polynesia (Clarke 1995). However, most species attain relatively small larval sizes (<12 mm standard length, Lo Yat unpubl. data) and typically have shallow body depths; thus, they may not have been retained by our nets. Due to the possibility of significant escapement, our study focused on the distribution patterns of late-stage larvae, rather than younger forms. However, as the survivors of demographic processes occurring in the plankton, patterns in the abundance and distribution of older larvae may impart more information on dispersal than those of younger larvae that are still undergoing, or have yet to experience, significant mortality.

Although there was a strong declining gradient in abundance of nearshore fish larvae with increasing distance from the shore, there were still large numbers (occasionally hundreds per hour) of larvae collected by the ECOTAP programme $>100 \mathrm{~km}$ from the nearest reef. This result suggests that a widespread dispersal and exchange of larvae is likely among patches of habitat separated by spatial scales of $<300 \mathrm{~km}$. At this spatial scale, demographic connectivity of reef fish populations via larval dispersal may be far more common than conceded by modelling studies and prevailing views of reef fish population dynamics.

This conclusion does not necessarily apply to all taxa of reef fishes, as the larvae we collected were a restricted subset of the species that occur in reef habitats, and, furthermore, included only those that had larval forms large enough to be retained by the net. Acanthurids, pleuronectiform larvae, ostraciids, fistularids, balistids, holocentrids, chaetodontids, mullids and carangids together composed $85 \%$ of catches, while acanthurids, holocentrids, fistularids, pomacanthids, lutjanids and pleuronectiform larvae accounted for $95 \%$ of catches of reef fishes $>150 \mathrm{~km}$ offshore (Table 1). Some evidence suggests that the life history traits of these taxa predispose them to long distance dispersal. For example, otolith studies show that larvae of acanthurids often have long pelagic lives relative to those taxa that were not present offshore, such as pomacentrids. Wilson \& McCormick (1999) found that pelagic larval durations of newly settled acanthurids collected on the Great Barrier Reef and in the Caribbean were often $>90 \mathrm{~d}$. In contrast, larval durations of pomacentrids at these localities were rarely >30 d. Moreover, there seems to be considerable intraspecific variation in larval durations of acanthurids. Bergenius et al. (2002) found that the pelagic larval duration of Acanthurus chirurgus collected the morning after settlement varied from 69 to as long as 90 d, while Doherty et al. (2004) found a similar range in pelagic duration (64 to $97 \mathrm{~d}$ ) within a single settlement cohort of the acanthurid Naso sp. collected on only a few nights of sampling in French Polynesia. Lengthy and variable pelagic durations may predispose larvae to long distance dispersal by extending the period they reside in the plankton where they may be entrained by currents away from reef habitats into open water.

Variation in the duration of larval life may reflect the capacity to delay metamorphosis into juvenile forms 
and extend the period of 'competence', when larvae attain the ability to settle into the benthic habitats of adults. Field experiments by McCormick (1999) demonstrated delayed metamorphosis in the absence of close physical association to reefs of late-stage larvae of the convict surgeonfish Acanthurus triostegus in French Polynesia. This behaviour is thought to be shared by other taxa of reef fishes that were also abundant in our offshore samples or have been frequently collected in oceanic waters remote from reefs, notably pleuronectiform and wrasse larvae (Victor 1986, 1987, Cowen 1991, May \& Jenkins 1992, Cowen \& Sponaugle 1997). For these taxa, evidence of delayed metamorphosis comes from otolith analysis, which reveals reduced growth during the later stages of larval life (see Leis \& McCormick 2002 for review). Species from other taxa that do not appear to have the ability to delay metamorphosis may achieve the same goal of extending competence in open water by having a 'staged' process of settlement in which the late-stage larvae and juveniles associate with floating objects or jellyplankton prior to settling on reefs (Kingsford 1993).

The offshore dispersal of a restricted suite of reef species has important implications for the management of reef fish populations. Assuming that these larvae are capable of returning to reefs and surviving the juvenile stage, our study suggests that there may be great differences in connectivity and, thus, the effective stock size of fishes inhabiting the same reefs. This implies that it is unlikely that a single size of marine protected areas will be suitable for all reef species. Additionally, widely dispersed species are more likely to be resilient to local extinction and disturbance events than those species whose larvae may only be found close to natal reefs, such as most pomacentrids. Conversely, widely dispersed species, such as acanthurids, chaetodontids and holocentrids, may require management strategies that encompass very large spatial scales if they are to be effective. For this reason, it is important that the frequency of broad-scale connectivity is assessed in reef fish populations and that the viability and postsettlement survivorship of larvae that have undergone offshore dispersal is determined. Recent developments in genetics and the analysis of otolith chemistry (e.g. Swearer et al. 1999) provide a means to investigate the fate of such larvae in reef habitats.

Acknowledgements. The authors thank the scientists, staff and crew of the vessels participating in the fieldwork for ECOTAP. We acknowledge the Service de la Pêche de la Polynésie Française, the Institut de la Recherche et du Développement and the Institut Français de Recherche pour l'Exploitation de la Mer, which supported the ECOTAP programme. We acknowledge the generosity of the scientists who allowed us access to data and to the larval fish samples that were collected as part of this programme. In particular, we thank Dr. François-Xavier Bard, Dr. Arnaud Bertrand, Christophe Misselis, Stephen Yen Kai Sun and Arsène Stein. We thank Drs. Mark McCormick, Jeff Leis and the anonymous referees for discussions and comments that substantially improved early drafts of this manuscript.

\section{LITERATURE CITED}

Bergenius MAJ, Meekan MG, Robertson DR, McCormick MI (2002) Larval growth predicts the recruitment success of a coral reef fish. Oecologia 131:521-525

Bertrand A, Le Borgne R, Josse E (1999) Acoustic characterisation of micronekton distribution in French Polynesia. Mar Ecol Prog Ser 191:127-140

Bertrand A, Bard F-X, Josse E (2002) Tuna food habits related to the micronekton distribution in French Polynesia. Mar Biol 140:1023-1037

Choat JH, Doherty PJ, Kerrigan BA, Leis JM (1993) A comparison of towed nets, purse-seine, and light-aggregation devices for sampling larvae and pelagic juveniles of coral reef fishes. Fish Bull 91:195-209

Clarke TA (1991) Larvae of nearshore fishes in oceanic waters near Oahu, Hawaii. NOAA Tech Rep NMFS 101

Clarke TA (1995) Larvae of nearshore fishes in oceanic waters of the central equatorial Pacific. Pac Sci 49: $134-142$

Cowen RK (1985) Large scale pattern of recruitment by the labrid Semicossyphus pulcher: causes and implications. J Mar Res 43:719-742

Cowen RK (1991) Variation in the planktonic larval duration of the temperate wrasse Semicossyphus pulcher. Mar Ecol Prog Ser 69:9-15

Cowen RK, Sponaugle S (1997) Relationship between early life history traits and recruitment among coral reef fishes. In: Chambers RC, Trippel EA (eds) Early life history and recruitment in fish populations. Chapman \& Hall, New York, p 423-449

Cowen RK, Lwiza KMM, Sponaugle S, Paris CB, Olson DB (2000) Connectivity of marine populations: open or closed? Science 287:857

Doherty PJ, Dufour V, Galzin R, Hixon MA, Meekan MG, Planes S (2004) High mortality during settlement is a population bottleneck for a tropical surgeonfish. Ecology 85: $2422-2428$

Hare JA, Cowen RK (1991) Expatriation of Xyrichtys novacula (Pisces: Labridae) larvae: evidence of rapid cross-slope exchange. J Mar Res 49:801-823

Heath MR (1992) Field investigations of the early life stages of marine fish. Adv Mar Biol 28:1-174

Kingsford MJ (1993) Biotic and abiotic structure in the pelagic environment: importance to small fish. Bull Mar Sci 53: 393-415

Leis JM (1983) Coral reef fish larvae (Labridae) in the East Pacific Barrier. Copeia 1983:826-828

Leis JM (1984) Larval fish dispersal and the East Pacific Barrier. Oceanogr Trop 19:181-192

Leis JM (1991) The pelagic stage of reef fishes: the larval biology of coral reef fishes. In: Sale PF (ed) The ecology of fishes on coral reefs. Academic Press, San Diego, CA, p 183-227

Leis JM (1993) Larval fish assemblages near Indo-Pacific coral reefs. Bull Mar Sci 53:362-392

Leis JM (2002) Pacific coral reef fishes: the implications of behaviour and ecology of larvae from biodiversity and conservation, and a reassessment of the open population paradigm. Environ Biol Fishes 65:199-208 
Leis JM, McCormick MI (2002) The biology, behavior, and ecology of the pelagic, larval stage of coral reef fishes. In: Sale PF (ed) Coral reef fishes-dynamics and diversity in a complex ecosystem. Academic Press, London, p 171-199

May HMA, Jenkins GP (1992) Patterns of settlement and growth of juvenile flounder Rhombosolea tapirina determined from otolith microstructure. Mar Ecol Prog Ser 79: 203-214

McCormick MI (1999) Delayed metamorphosis of a tropical reef fish (Acanthurus triostegus): a field experiment. Mar Ecol Prog Ser 176:25-38

Mora C, Sale PF (2002) Are populations of coral reef fish open or closed? Trends Ecol Evol 17:422-428

Paris CB, Cowen RK (2004) Direct evidence of a biophysical retention mechanism for coral reef fish larvae. Limnol Oceanogr 49:1964-1979

Randall JE (1985) Fishes. In: Delesalle B, Galzin R, Salvat B (eds) Fauna and flora, a first compendium of French Polynesia sea dwellers. Proc 5th Int Coral Reef Congr, Vol 1. Antenne Museum-EPHE, Moorea, p 462-481

Roberts CM (1997) Connectivity and management of Caribbean coral reefs. Science 278:1454-1457

Robertson DR, Allen GR (1996) Zoogeography of the shore

Editorial responsibility: Howard Browman (Associate Editorin-Chief), Storebø, Norway fishes fauna from Clipperton Atoll. Coral Reefs 15: 121-131

Swearer S, Caselle J, Lea D, Warner R (1999) Larval retention and recruitment in an island population of a coral-reef fish. Nature 402:799-802

Taylor MS, Hellberg ME (2003) Genetic evidence for local retention of pelagic larvae in a Caribbean reef fish. Science 299:107-109

Victor BC (1986) Delayed metamorphosis with reduced larval growth in a coral reef fish (Thalassoma bifasciatum). Can J Fish Aquat Sci 43:1208-1213

Victor BC (1987) Growth dispersal and identification of planktonic labrid and pomacentrid reef-fish larvae in the eastern Pacific Ocean. Mar Biol 95:145-152

Victor BC, Wellington GM (2000) Endemism and the pelagic larval duration of reef fishes in the eastern Pacific Ocean. Mar Ecol Prog Ser 205:241-248

Wilson DT, McCormick MI (1999) Microstructure of settlement-marks in the otoliths of tropical reef fishes. Mar Biol 134:29-40

Young PC, Leis JM, Hausfeld HF (1986) Seasonal and spatial distribution of fish larvae in waters over the North West Continental Shelf of Western Australia. Mar Ecol Prog Ser 31:209-222

Submitted: March 1, 2005; Accepted: March 7, 2006

Proofs received from author(s): October 6, 2006 